\title{
Components of stallion seminal plasma and their influence on spermatozoa
}

\author{
Terttu Katila and Maria Kareskoski \\ University of Helsinki, Faculty of Veterinary Medicine, Department of Clinical Veterinary Sciences, Saari Unit, Saarentaus, Finland
}

\begin{abstract}
Summary
This review focuses on the composition of stallion seminal plasma and on its role as a storage medium of spermatozoa, with special reference to artificial insemination (Al). The stallion ejaculates in 6-9 jets resulting from urethral contractions, and these jets have characteristic volumes, sperm concentrations and composition. Different types of open-ended or closed artificial vaginas (AVs) are available for semen collection, and ejaculatory jets can be collected separately as a fractionated ejaculate, using an open-ended AV or an automated phantom (Equidame ${ }^{\circledR}$ ). Seminal plasma influences spermatozoa during storage in different ways depending on dilution ratios, duration of storage and other factors. Beneficial effects have been reported after seminal plasma addition before freezing, but contradictory results show that short-term exposure (15 min) of sperm to seminal plasma has no effect on sperm motility or viability, and prolonged exposure $(2,4$ or 6 h) to 5 or $20 \%$ seminal plasma in the freezing dilvent is deleterious. The optimal proportion of seminal plasma for cooled storage seems to be fairly low. Figures from 0 to $20 \%$ have been reported in different studies. There is some evidence that the sperm-rich fractions of the ejaculate would be more suitable for freezing than the whole ejaculate or the sperm-low fractions. Seasonal and individual variation is seen in the composition and quality of stallion seminal plasma. Research on the biochemical composition of whole and fractionated stallion ejaculates, mainly concerning the levels of enzymes, carbohydrates, lipids, electrolytes and minerals, and compounds involved in the protection of sperm from oxidative damage is reviewed.
\end{abstract}

Keywords: horse, reproduction, seminal plasma, spermatozoa, cryopreservation, cooled semen

\section{Zusammensetzung des Seminalplasmas beim Hengst und dessen Einfluss auf die Spermien}

Dieser Übersichtsartikel befasst sich mit der Zusammensetzung des Seminalplasmas beim Hengst und dessen Bedeutung als Komponente in konserviertem Sperma unter besonderer Berücksichtigung der praktischen Anforderungen in der equinen Samenübertragung. Mithilfe urethraler Kontraktionen erfolgt die Ejakulation beim Hengst in 6-9 Fraktionen; diese Fraktionen unterscheiden sich hinsichtlich des Volumens, der Spermienkonzentration und der Zusammensetzung. Verschiedene Typen (geschlossene und offene Modelle) künstlicher Vaginen werden zur Samengewinnung eingesetzt. Die verschiedenen Ejakulatfraktionen können manuell - mit offenem Scheidenmodell - oder mithilfe eines automatisierten Phantoms (Equidame ${ }^{\circledR}$ ) separat gewonnen werden. Seminalplasma beeinflusst die Spermien während der Lagerung in Abhängigkeit vom Verdünnungsgrad, der Lagerungsdauer und weiteren Faktoren. Positive Effekte auf die Spermaqualität wurden durch Seminalplasmazugabe vor der Tiefgefrierung des Samens erzielt; im Gegensatz dazu wird jedoch beschrieben, dass eine kurzzeitige Exposition (15 Min.) von Spermien mit Seminalplasma keine Effekte auf Spermienmotilität und -viabilität bedingt, eine prolongierte Exposition (2, 4 oder 6 Std.) von 5-20\% Seminalplasmaanteil im Gefrierverdünner jedoch die Spermaqualität negativ beeinträchtigt. Die optimale Seminalplasmakonzentration für die gekühlte Lagerung flüssigkonservierten Hengstspermas scheint ziemlich niedrig zu sein, wobei in der Literatur die Angaben zwischen 0-20\% schwanken. Für die Samentiefgefrierung sind die spermienreichen Fraktionen des Hengstejakulates im Vergleich zum Gesamtejakulat oder den spermienarmen Fraktionen wahrscheinlich besser geeignet. Saisonale und individuelle Variationen in der Zusammensetzung und Qualität equinen Seminalplasmas sind besonders hervorzuheben. Forschungsarbeiten zur biochemischen Zusammensetzung anhand vollständig und fraktioniert gewonnener Hengstejakulate werden hinsichtlich der Gehalte an Enzymen, Carbohydraten, Lipiden, Elektrolyten und Mineralien aufgeführt; des weiteren werden die Faktoren und Mechanismen von Spermien zum Schutz vor oxidativem Stress erläutert.

Schlüsselwörter: Pferd, Reproduktion, Seminalplasma, Spermatozoen, Kryokonservierung, gekühlter Samen

\section{Introduction}

Seminal plasma is secreted by the accessory sex glands and mixed with spermatozoa during ejaculation. Seminal fluid is a vehicle that is needed for the movement of spermatozoa in the genital tracts of the male and female. This fluid is a complex mixture of proteins, ions and organic substances of low molecular weight, such as free amino acids, monosaccharides, lipids, polyamines, prostaglandins and steroid hormones. Probably more important than components in the fluid are the seminal plasma derived proteins that attach to sperm cell membranes. Seminal plasma facilitates transport, protection and nutrition of spermatozoa in the female genital tract.
Seminal factors exert negative and positive regulation in sperm capacitation, acrosome reaction and gamete interaction (Töpfer-Petersen et al. 1998). This review focuses on the composition of stallion seminal plasma and on its role as a storage medium of spermatozoa with special reference to artificial insemination (Al).

\section{Ejaculation of the stallion}

The ejaculation is preceded by the dripping of clear pre-ejaculatory fluid from the urethra during the intromission and copu- 
latory movements. The stallion ejaculates in 6-9 jets resulting from the contractions of the urethra. The first three jets contain $3 / 4$ of total sperm numbers, and therefore, the term sperm-rich is used for the first part of the ejaculate. Semen volume, sperm concentration and concentrations of many substances decrease towards the end of the ejaculation (Kosiniak 1975).

Magistrini et al. (2000) used an automated semen collection device to collect fractionated ejaculates (Lindeberg et al. 1999) and $1^{\mathrm{H}}$ magnetic resonance spectroscopy to quantify molecules defined as markers of sex gland secretions. Carnitine, glycerylphosphorylcholine and choline were markers for the epididymes, $\mathrm{N}$-acetyl function of glycoproteins and spermine for ampullae, acetic acid for the bulbourethral glands and citric acid for seminal vesicles. Lactic acid is the main component of the prostate secretions (Magistrini et al. 1995), but it was not included in the analysis. Secretions from the epididymes and ampullae were associated with the spermrich fractions, and seminal vesicle secretions appeared during the last fractions. Acetic acid concentration did not differ between the fractions, which suggests that it was not a specific marker for bulbourethral glands.

\section{Semen collection in stallions}

Semen is usually collected by an artificial vagina (AV) although manual manipulation is also possible. There are two types of $\mathrm{AVs}$ : in open-ended ones semen is collected directly from the urethra into a receptacle, whereas in closed models semen is directed into a collection bottle attached to the end of the AV. Closed AVs are routinely used in stud farms, and the most common models are the Missouri, Colorado, Hannover and Nishikawa models (Love 1992).

The open-ended AV (Krakow model) allows the collection of individual ejaculatory jets (Tischner et al. 1974). It can also be used to separate the first sperm-rich jets from the last jets with low sperm concentration. This method is preferred for stallions with low sperm concentration to avoid centrifugation of semen. Low concentration is a problem in cooled fresh semen storage, because adequate dilution of semen $(1: 4=$ semen:extender) would result in too low sperm concentrations $\left(<20 \times 10^{6} / \mathrm{ml}\right)$ (Varner et al. 1987).

The fractionation achieved using an open-ended AV was further developed in a computer-assisted phantom (Equidame ${ }^{\circledR}$ ), which is equipped with a detachable open-ended AV, metallic funnel, and a semen collection tray. The tray houses 5 plastic cups, the semen volumes of which can be set to 10,20, 30 or $40 \mathrm{ml}$. The computer-controlled tray moves horizontally and collects semen into the cups during ejaculation (Lindeberg et al. 1999). The fractions collected are not necessarily the same as the ejaculatory jets, because the tray moves when the predetermined weight of the cup is achieved (Fig. 1). Fractionated ejaculates allow biochemical and functional analyses of different parts of the ejaculate (Kareskoski et al. 2005).

\section{Role of seminal plasma in semen storage}

Cooled storage of fresh semen requires addition of extenders, most commonly skim milk based extenders, that pro- tect spermatozoa from cold shock and provide buffering and nutrients for sperm. Dilution of semen with extender decreases the proportion of seminal plasma, which is beneficial for storage. It is known that the presence of $40-50 \%$ seminal plasma during storage for $24-48 \mathrm{~h}$ is detrimental to sperm motility (Jasko et al. 1991, Pruitt et al. 1993). A proportion of $20 \%$ seminal plasma (dilution ratio of semen:extender of 1:4) did not have negative effects on



Fig 1 A typical fractionated semen collection with the Equidame ${ }^{\circledR}$ phantom. Cup 1 contains pre-ejaculatory fluid, cups 2 and 3 sperm-rich fractions and cups 4 and 5 low-sperm fractions with possible gel.

Typische fraktionierte Samengewinnung mit dem Equidame ${ }^{\circledR}$. Phantom. Cup 1 enthält das präejakulatorische Sekret, Cup 2 und Cup 3 die spermienreichen und Cup 4 und 5 die spermienarmen Fraktionen mit möglichem Gel.

sperm characteristics during storage for 24 or $48 \mathrm{~h}$ in the experiments of Jasko et al. (1992) and Rigby et al. (2001), but others have reported seminal plasma concentrations of $\leq 10 \%$ to be superior to $20 \%$ during storage for $48 \mathrm{~h}$ (Palmer 1984, Pruitt et al. 1993). The optimal seminal plasma concentration may be even lower than that; Todd et al. (2001) found higher progressive sperm motility after 24 and $48 \mathrm{~h}$ of cooled storage in the samples that contained 1.25 or $2.5 \%$ of seminal plasma than in samples containing $10 \%$.

In many studies, centrifugation of semen, removal of supernatant and subsequent resuspension into skim milk extender have improved sperm motility as compared to non-centrifuged samples (Palmer 1984, Jasko et al. 1991, Pruitt et al. 1993, Langkammer 1994, Sieme et al. 2001, Todd et al. 2001), but in some other studies the total removal of seminal plasma and replacement with skim milk extender has decreased motility after 24-h storage (Padilla and Foote 1991, Jasko et al. 1992, Rigby et al. 2001, Kareskoski et al. 2006). If all seminal plasma is removed, skim milk is not a suitable extender. Addition of a modified high-potassium Tyrode's medium to skim milk extender during cooled storage of $\geq 24 \mathrm{~h}$ in the total absence of seminal plasma has yielded good sperm motility; but if any seminal plasma is left, skim milk alone is better than addition of Tyrode's medium (Padilla and Foote 1991, Webb and Arns 1995, Rigby et al. 2001). The effect of seminal plasma during storage may also depend on the temperature; $5^{\circ} \mathrm{C}$, room temperature and $40^{\circ} \mathrm{C}$ have given different results (Wöckener et al. 1990, Sieme et al. 2001). 
Since the majority of spermatozoa are in the first ejaculatory jets and a large proportion of seminal plasma lowers motility during cooled storage, the first sperm-rich part of the ejaculate has been processed for storage and the last sperm-low part discarded. Varner et al. (1987) demonstrated higher sperm motility after cooled storage of 12 or $24 \mathrm{~h}$ in the sperm-rich part than in the whole ejaculate. Similarly, Langkammer (1994) reported higher loss in sperm motility after cooled storage of 24 or $72 \mathrm{~h}$ in the whole ejaculate collected by Missouri AV than in the sperm-rich part collected by Krakow AV. However, centrifugation of the whole ejaculate as well as of the spermrich part further improved sperm motility during storage.

Contrasting results were reported by Katila et al. (2006). Percentage of spermatozoa with intact plasma membranes and all of the studied motility characteristics of spermatozoa, except total motility, were significantly higher for spermatozoa in sperm-poor seminal plasma than in sperm-rich seminal plasma after cooled storage of $24 \mathrm{~h}$. Conflicting results can perhaps be explained by different division of ejaculates into sperm-rich and sperm-poor parts.

Kareskoski et al. (2006) attempted to separate pre-ejaculatory fluid (Cup 1) from the first sperm-rich fraction). The spermrich part was fractionated into two separate cups (Cups 2 and 3). The sperm-low part was collected into Cup 4 and the whole ejaculate was obtained by taking the same proportion from all cups. No significant differences in motility or viability between cups or the whole ejaculate were observed after cooled storage of $24 \mathrm{~h}$. Although no significant differences between cups were detected by Katila et al. (2004), sperm motility values were higher in Cup 3 (the last part of the sperm-rich fraction). The number of stallions in these two studies was only four, and therefore statistical significance difficult to reach. In the boar, spermatozoa in the last part of the ejaculate seem to be less sensitive to the stress during storage (Pena et al. 2003). Further studies are needed in the stallion, but at this point in time it seems that differences between stallions are more pronounced than differences between ejaculatory fractions.

\section{Seasonal and individual variations in seminal plasma composition and quality}

Horses are seasonal breeders. Not only is the reproduction of mares affected by season but also that of the stallions. Seasonal effects on seminal plasma seem to be more pronounced than on sperm characteristics (Gebaver et al. 1976). The seasonal differences in the seminal plasma composition of stallions (Abou-Ahmed et al. 1993) are probably caused by changes in sex steroid levels of stallions, which have been shown to exhibit seasonal variation both in blood and seminal plasma (Braun et al. 1996, Hoffmann and Landeck 1999).

The hormonal balance of a stallion can change in diseases, during hard training and racing (Janett et al. 2005), and medication. As a result, semen quality including spermatozoa and the composition and functional capacity of seminal plasma can become different. E.g. dexamethasone treatment of stallions increased total protein and iron concentrations of seminal plasma but decreased alkaline phosphatase levels (Danek 2001). Stallions exhibit major differences in semen quality. This is mostly due to differing quality of spermatozoa, but also the quality of seminal plasma can vary. Aurich et al. (1996) added $30 \%$ of seminal plasma from stallions with high post-thaw sperm motility to ejaculates with low motility and vice versa before freezing of semen. "Good" seminal plasma increased progressive motility and membrane integrity of sperm postthawing, whereas "bad" seminal plasma decreased motility. Katila et al. (2004) noted that exchange of seminal plasma between stallions changed motility parameters and the percentage of viable cells in some ejaculate fractions for one pair of stallions after 24-h cooled storage of fresh semen. On the other hand, addition of homologous vs. heterologous seminal plasma to cooled semen did not make a difference in sperm motility at 24 or $48 \mathrm{~h}$ (Todd et al. 2001).

Brinsko et al. (2000) had two types of stallions in their study: "good coolers" and "bad coolers". The difference between the two was the reduction in progressive sperm motility after $24 \mathrm{~h}$ of cooling, $\leq 30 \%$ and $\geq 40 \%$, respectively. Centrifugation and partial removal of seminal plasma (90\%) increased the percentage of progressively motile spermatozoa of "bad coolers" after $48 \mathrm{~h}$ of cooling. At $24 \mathrm{~h}$ the effect was not so obvious. The authors concluded that components of seminal plasma adversely affect sperm motion characteristics after cooling and storage and that these effects are independent of their concentration. Some stallions will benefit from centrifugation and seminal plasma removal, especially if the semen is stored $>24 \mathrm{~h}$.

\section{Biochemical components of seminal plasma}

This review focuses on compounds studied in stallion seminal plasma. Compared to other species and humans, limited data is available on the stallion, and therefore research on other mammalian species is also discussed. It is well known that variation exists both between different individuals (Amann et al. 1987) and different species (Aumüller et al. 1990, Massanyi et al. 2003); extrapolations between species are not always meaningful. Although seminal plasma proteins are an essential part of seminal plasma and have received a substantial amount of attention in recent publications, they are not included in this review.

\section{Carbohydrates and lipids}

The amount of carbohydrates in stallion seminal plasma (after gel removal) is considerably lower than in bull semen (Gebaver et al. 1976). Of the free carbohydrates, some inositol and glucose are found in stallion seminal plasma, but only negligible amounts of fructose and no galactose. Galactose is the main type of bound carbohydrate in stallion seminal plasma, but also glucose, mannose and fucose are detected (Baronos et al. 1971). Stallion spermatozoa are not effective in using fructose anaerobically (Mann et al. 1963). The carbohydrate elements in glycoproteins and glycopeptides, along with lipids in the sperm membrane, have been a more frequently studied subject than free carbohydrates and lipids. Cholesterol is the main sterol in sperm membranes of the boar, bull, stallion and rooster, and choline and ethanolamine phosphoglycerides and sphingomyelin are the major types of phospholipids (Parks and Lynch 1992). Stallion semen also contains prostasome-like particles with a characteristic lipid 
profile and high amounts of cholesterol and sphingomyelin (Arienti et al. 1998). These membrane vesicles are found mainly in the sperm-rich part of the ejaculate, but their origin and function are not known (El-Haii Ghaoui et al. 2004).

\section{Sodium, chloride and potassium}

Much remains to be elucidated about the regulation of $\mathrm{pH}$ and the ion content of spermatozoa and their environment. The internal $\mathrm{pH}$ of spermatozoa, which changes during capacitation, is highly dependent on the $\mathrm{pH}$ outside the cell, because sperm have only limited regulatory mechanisms (reviewed by Hamamah and Gatti 1998). Concentrations of sodium, potassium and chloride vary significantly between stallions (Amann et al. 1987). Pre-sperm fluid contains the highest concentrations of chloride, and the last parts of the ejaculate have higher chloride content than the sperm-rich fractions. No differences are seen in sodium or potassium concentrations between ejaculatory fractions (Kareskoski et al. 2005). The addition of potassium to semen extenders improves motility of stallion (Padilla and Foote 1991) and human sperm (Karow et al. 1992), but Rossato et al. (2002) found no correlation between the ionic composition and the osmolarity of human seminal plasma. Intracellular concentrations of potassium are higher than those of seminal plas$\mathrm{ma}$, and therefore potassium levels are linked to sperm concentration. In sheep, increasing potassium levels are negatively correlated to progressive motility, while the reverse is true for sodium and chloride (Abdel-Rahman et al. 2000).

\section{Calcium, magnesium and phosphate}

In a study by Barrier-Battut et al. (2002), variation in the concentrations of calcium, magnesium, copper and zinc in stallion seminal plasma did not affect freezability. Pre-sperm fluid and the first sperm-rich fraction contain low levels of calcium and magnesium, while the first sperm-rich fraction has high phosphate concentrations (Kareskoski et al. 2005). In sheep ejaculates, intracellular calcium and magnesium concentrations were higher than in seminal plasma as opposed to phosphate levels. Furthermore, lower values of progressive motility were correlated to increasing levels of calcium and decreasing magnesium and phosphate concentrations (Abdel-Rahman et al. 2000). In contrast, post-thaw motility values in bull semen increased when $\mathrm{MgCl}_{2}$ was added to the freezing extender (Lapointe et al. 1996), which may indicate substantial variation between species. Another explanation is that perhaps the effect of ions on motility is altered during storage. Calcium is involved in many events in the reproductive tract of both the stallion and the mare. Spontaneous acrosome reactions were associated with increased concentrations of ionized calcium in stallion seminal plasma (Pesch 2005). Extracellular calcium regulates sperm capacitation (Baker et al. 2004) and hyperactivation (Marquez and Suarez 2004), which has been shown in human semen.

\section{Zinc, copper and iron}

The concentrations of copper and zinc, but not iron, in stallion seminal plasma differed between semen samples of nor- mal and poor quality (Pesch 2005). The same study found a significant correlation between fertility and the concentration of zinc in summer and late autumn, but not in spring. Massanyi et al. (2003) studied seminal concentrations of various trace elements in several animal species. Zinc and iron levels were positively correlated in stallion and bull semen. Boar semen contained more zinc than semen from stallions or bulls. In addition, copper and iron concentrations were higher in ram semen compared with stallions and boars. Spermchromatin stability in human ejaculates is zinc-dependent and zinc levels can affect pregnancy rates (as reviewed by Biörndahl and Kvist 2003). In human semen samples, high zinc concentrations were associated with a decrease in progressive motility, but zinc concentrations did not affect time to pregnancy (Sorensen et al. 1999).

\section{Seminal plasma enzymes}

Several enzymes have been identified in stallion seminal plasma, and effort has been put into finding correlations between certain enzyme activities and semen quality. Studies have also focused on determining the origin of the identified enzymes in the reproductive organs, but in most cases the physiological function of these compounds remains unclear. In canine semen, levels of acid phosphatase (ACP) activity reflect prostate function (James et al. 1979), but in the stallion, studies on this enzyme have so far been limited to epididymal tissue (Lopez et al. 1989). Alkaline phosphatase (AP) activity seems to be derived mainly from the testis and epididymis and thus AP and ACP are positively correlated to the sperm count and negatively to semen volume (Pesch 2005). In fractionated stallion ejaculates, ACP levels were highest in the first sperm-rich fraction, while there were no differences in AP levels between fractions (Kareskoski et al. 2005). AP and perhaps also ACP can be used to verify ejaculation and tubular patency in stallions (Turner and McDonnell 2003, Pesch 2005).

Levels of $\beta$-glucuronidase (BGase) vary between different fractions of stallion ejaculates, and the highest levels have been found in the first sperm-rich fraction (Kareskoski et al. 2005). Dias et al. (2004) identified $\alpha$ - 1,4-glucosidase activity in stallion seminal plasma and epididymis with increasing activity from the proximal caput to the cauda. Among these seminal plasma glycosidases, at least BGase and Nacetyl- $\beta$-D-glucosaminidase (NAGase) bind with high affinity to the sperm surface and may play a part in modifying the sperm surface before fertilization (Barbieri et al. 1996) and cause dispersion of the cumulus oophorus cells (Rethinaswamy et al. 1994). Levels of $\alpha$-galactosidase, $\beta$-galactosidase and NAGase have been shown to differ significantly between infertile men with oligo-astheno-teratozoospermia and fertile controls (Corrales et al. 2000). As these glycosidases presumably play important roles during sperm maturation and fertilization, differences in their levels may be associated with functional sperm defects (Corrales et al. 2002). In the bull, low sperm concentrations and abnormal morphology have been associated with decreased levels of glycosidases derived from the epididymis or spermatozoa, such as NAGase, $\alpha$-fucosidase, $\beta$-galactosidase, BGase and neutral $\alpha$-mannosidase (Jauhianen and Vanha-Perttula 1987). 
Lipase activity has been demonstrated in stallion seminal plasma and it decreases sperm motility in a dose-dependent manner (Carver and Ball 2002). Among other enzymes studied in equine seminal plasma are the carbonic anhydrase isoenzymes (CA-I, CA-II and CA-III) that are assumed to regulate the bicarbonate concentration, and thus, the $\mathrm{pH}$ of seminal plasma. Activities of CA-I, CA-II and CA-III were detected in the seminal vesicles, prostate and bulbourethral glands (Asari et al. 1996). Angiotensin-converting enzyme (ACE) has been found in the plasma membranes of ejaculated and epididymal spermatozoa and in post-pubertal testes. Angiotensin II influenced some sperm motility parameters, such as average path velocity and curvilinear velocity, but not the percentage of motile sperm (Ball et al. 2003). In the thesis of Pesch (2005), activities of lactate dehydrogenase, aspartate aminotransferase, glutamate dehydrogenase, gamma-glutamyltransferase and creatine kinase were measured in stallion seminal plasma and their effect on sperm quality assessed. Of the enzymes studied, only lactate dehyrogenase was correlated to motility, sperm count and volume. Platelet-activating factor (PAF) acetylhydrolase activity has also been detected in the semen of several mammalian species including the stallion. Sperm-derived PAF stimulates sperm motility and is involved in capacitation, and the PAF acetylhydrolase was suggested as its inhibitor (Hough and Parks 1994).

Proteolytic enzymes of the matrix-metalloproteinase (MMP) family have been studied in many tissues and secretions, including the seminal plasma of humans and a few animal species. Métayer et al. (2002) characterized proteinases and proteinase inhibitors from different regions of the epididymis in rams, boars and stallions. One of the main metalloproteinases from the caput epididymis of the ram and stallion was identified as the pro-form of MMP-2. MMP-3 and MMP-9 and proteinase inhibitors were found in epididymal fluids of all three species. The two gelatinases MMP-2 and MMP-9 and their pro-forms are present in human seminal plasma (Shimokawa et al. 2002). In humans, MMP levels and profiles are correlated with semen characteristics such as sperm concentration, sperm morphology and motility (Baumgart et al. 2002, Buchman-Shaked et al. 2002).

\section{Sperm protection from oxidative damage}

Catalase, glutathione peroxidase (GPX) and superoxide dismutase (SOD) protect spermatozoa from oxidative damage caused by the production of reactive oxygen species (ROS). Cryodamaged or morphologically abnormal sperm, and also neutrophils, are significant sources of ROS (Ball et al. 2001, Baumber et al. 2002). Hydrogen peroxide is the main ROS that can harm spermatozoa during storage; ROS lower motility values (Baumber et al. 2000) and cause DNA fragmentation (Baumber et al. 2003) and membrane damage of spermatozoa due to lipid peroxidation (Ball et al. 2000). Variation between species in sperm membrane composition may be related to the cold shock sensitivity of sperm (Parks and Lynch 1992). Some of the decrease in motility after exposure to ROS can be spontaneously reversed in 6 to 24 hours because of endogenous repair mechanisms (De Lamirande and Gagnon 1992). The ROS production may have a physiological role as it promotes capacitation and tyrosine phosphory- lation (Baumber et al. 2003), which is involved in the signalling pathway controlling capacitation and the acrosome reaction (Leyton et al. 1992). In a review, Griveau and le Lannou (1997) concluded that small amounts of ROS are needed for normal sperm function, but excessive ROS production is highly toxic to sperm. ROS levels detected in the semen of infertile men are more likely to be caused by increased ROS production rather than a decreased ROS scavenging capacity (Zini et al. 1993).

The highest levels of catalase activity in the reproductive tract of the stallion are found in the prostate gland (Ball et al. 2000). Catalase is found in high amounts in all fractions of the ejaculate except for the pre-sperm fluid (Koskinen et al. 2002), which could indicate that the prostate contributes to several ejaculatory fractions or that catalase originates also in other glands. GPX is one of the major protein compounds secreted in the epididymis of the stallion (Fouchécourt et al. 2000) and the testes and sperm from the cauda epididymis contain more GPX activity than other reproductive tissues. Enzymatic protection against oxidative damage is mainly due to seminal plasma, because of limited GPX- and SOD-like activity of the spermatozoa (Baumber and Ball 2005). Despite an apparent physiological function of these enzymes, adding antioxidant to the freezing extender does not seem to improve sperm survival during storage (Baumber et al. 2005).

\section{Literature}

Abdel-Rahman H. A., El-Belely M. S., Al-Qarawi A. A. and El-Mougy S. A. (2000): The relationship between semen quality and mineral composition of semen in various ram breeds. Small. Rum. Res. 38, 45-49

Abou-Ahmed M. M., El-Belely M. S., Ismail, S. T., El-Baghdad, Y. R. M. and Hemeida N. A. (1993): Influence of age and season on certain biochemical constituents of seminal plasma of Arabian horses. Anim. Reprod. Sci. 32, 237-244

Amann R. P., Cristanelli M. J. and Squires E. L. (1987): Proteins in stallion seminal plasma. J. Reprod. Fert. Suppl. 35, 113-120

Arienti G., Carlini E., De Cosmo A. M., Di Profio P. and Palmerini C. A. (1998): Prostasome-like particles in stallion semen. Biol. Reprod. 59, 309-313

Asari M., Sasaki K., Miura K., Ichihara N. and Nishita T. (1996): Immunohistolocalization of the carbonic anhydrase isoenzymes (CA-I, CA-II and CA-III) in the reproductive tract of male horses. Am. J. Vet. Res. 57, 439-443

Aumüller G., Seitz J., Lilia H., Abrahamsson P.-A., von der Kammer H. and Scheit K.-H. (1990): Species- and organ-specificity of secretory proteins derived from human prostate and seminal vesicles. Prostate 17, 31-40

Aurich J. E., Kühne A., Hoppe H. and Aurich C. (1996): Seminal plasma affects membrane integrity and motility of equine spermatozoa after cryopreservation. Theriogenology 46, 791-797

Baker M. A., Hetherington L., Ecroyd H., Roman S. D. and Aitken R. J. (2004): Analysis of the mechanisms by which calcium negatively regulates the tyrosine phosphorylation cascade associated with sperm capacitation. J. Cell. Sci. 117, $211-222$

Ball B. A., Gravance C. G., Medina V., Baumber J. and Liu I. K. M. (2000): Catalase activity in equine semen. Am. J. Vet. Res. 61, 1026-1030

Ball B. A., Gravance C. G., Wessel M. T. and Sabeur K. (2003): Activity of angiotensin-converting enzyme (ACE) in reproductive tissues of the stallion and effects of angiotensin II on sperm motility. Theriogenology 59, 901-914 
Ball B. A., Vo A. T. and Baumber J. (2001): Generation of reactive oxygen species by equine spermatozoa. Am. J. Vet. Res. 62, 508515

Barbieri M. A., Veisaga M. L., Paolichi F., Fornes M. W., Sosa M. A., Mayorga L. S., Bustos-Obregón E. and Bertini F. (1996): Affinity sites for $\beta$-glucuronidase on the surface of human spermatozoa. Andrologia 28, 327-333

Baronos S. (1971): Seminal carbohydrate in boar and stallion. J. Reprod. Fert. 24, 303-305

Barrier-Battut I., Delajarraud H., Legrand E., Bruyas J.-F., Fiéni F., Tainturier D., Thorin C. and Pouliquen H. (2002): Calcium, magnesium, copper, and zinc in seminal plasma of fertile stallions, and their relationship with semen freezability. Theriogenology 58, 229-232.

Baumber J. and Ball B. A. (2005): Determination of glutathione peroxidase and superoxide dismutase-like activities in equine spermatozoa, seminal plasma, and reproductive tissues. Am. J. Vet. Res. 66, 1415-1419.

Baumber J., Ball B. A., Gravance C. G., Medina V. and Davies-Morel M. C. (2000): The effect of reactive oxygen species on equine sperm motility, viability, acrosomal integrity, mitochondrial membrane potential, and membrane lipid peroxidation. J. Androl. 21 , 895-902

Baumber J., Ball B. A. and Linfor J. J. (2005): Assessment of the cryopreservation of equine spermatozoa in the presence of enzyme scavengers and antioxidants. Am. J. Vet. Res. 66, 772-779

Baumber J., Sabeur K., Vo A. and Ball B. A. (2003): Reactive oxygen species promote tyrosine phosphorylation and capacitation in equine spermatozoa. Theriogenology 60, 1239-1247

Baumber J., Vo A., Sabeur K. and Ball B. A. (2002): Generation of reactive oxygen species by equine neutrophils and their effect on motility of equine spermatozoa. Theriogenology 57, 1025-1033.

Baumgart E., Lenk S. V., Loening S. A. and Jung K. (2002): Quantitative differences in matrix metalloproteinase (MMP)-2, but not in MMP-9, tissue inhibitor of metalloproteinase (TIMP)-1 or TIMP-2, in seminal plasma of normozoospermic and azoospermic patients. Hum. Reprod. 17, 2919-2923

Björndahl L. and Kvist U. (2003): Sequence of ejaculation affects the spermatozoon as a carrier and its message. Reprod. Biomed. Online 70, 440-448

Braun J., Muto Y., Sato K. and Schallenberger E. (1996): Der Einfluss von Jahreszeit und sexueller Beanspruchung auf die Konzentration von Testosteron und Östradiol-17 $\beta$ im Seminalplasma beim Hengst (Influence of season and ejaculation frequency upon concentrations of testosterone and estradiol- $17 \beta$ in seminal plasma of stallions). Tierärztl. Prax. 24, 577-580

Brinsko S. P., Crockett E. C. and Squires E. L. (2000): Effect of centrifugation and partial removal of seminal plasma on equine spermatozoal motility after cooling and storage. Theriogenology 54 129-136

Buchman-Shaked O., Kraiem Z., Gonen Y. and Goldman S. (2002): Presence of matrix metalloproteinases and tissue inhibitor of matrix metalloproteinase in human sperm. J. Androl. 23, 702-708

Carver D. A. and Ball B. A. (2002): Lipase activity in stallion seminal plasma and the effect of lipase on stallion spermatozoa during storage at $5^{\circ} \mathrm{C}$. Theriogenology $58,1587-1595$

Corrales J. J., Burgo R. M., Miralles J. M. and Villar E. V. (2000): Abnormalities in sperm acid glycosidases from infertile men with idiopathic oligoasthenoteratozoospermia. Fertil. Steril. 73, 470-478

Corrales J. J., Burgo R. M., Galindo P., Muñoz-Barroso I., Miralles J. M. and Villar E. V. (2002): Abnormal expression of acid glycosidases in seminal plasma and spermatozoa from infertile men with varicocele. Reproduction 123, 411-417

Danek J. (2001): Effect of dexamethasone treatment on the biochemical characteristics of the stallion semen. Bull. Vet. Inst. Pulawy $45,275-280$

De Lamirande E. and Gagnon C. (1992): Reactive oxygen species and human spermatozoa I. Effects on the motility of intact spermatozoa and on sperm axonemes. J. Androl. 13, 368-378

Dias A. J., Maia M. S., Retamal C. A. and Lopez M. L. (2004): Identification and partial characterization of a-1,4-glucosidase activity in equine epididymal fluid. Theriogenology 61, 1545-1558
El-Haii Ghaovi R., Thomson P. C., Evans G. and Maxwell W. M. C. (2004): Characterization and localization of membrane vesicles in ejaculate fractions from the ram, boar and stallion. Reprod. Dom. Anim. 39,173-180

Fouchécourt S., Métayer S., Locatelli A., Dacheux F. and Dacheux J.L. (2000): Stallion epididymal fluid proteome: qualitative and quantitative characterization; secretion and dynamic changes of major proteins. Biol. Reprod. 62, 1790-1803

Gebaver M. R., Pickett B. W., Faulkner L. C., Remmenga E. E. and Berndtson W. E. (1976): Reproductive physiology of the stallion. VII. Chemical characteristics of seminal plasma and spermatozoa. J. Anim. Sci. 43, 626-632

Griveau J. F. and Le Lannou D. (1997): Reactive oxygen species and human spermatozoa: physiology and pathology. Int. J. Androl. 20, 61-69

Hamamah S. and Gatti J.-L. (1998): Role of the ionic environment and internal pH on sperm activity. Hum. Reprod. 13, 20-30

Hoffmann B. and Landeck A. (1999): Testicular endocrine function, seasonality and semen quality of the stallion. Anim. Reprod. Sci. 57, 89-98

Hough S. R. and Parks J. E. (1994): Platelet-activating factor acetylhydrolase activity in seminal plasma from the bull, stallion, rabbit and rooster. Biol. Reprod. 50, 912-916

James R. W., Heywood R. and Street A. E. (1979): Biochemical observations on beagle dog semen. Vet. Rec. 104, 480-482

Janett F., Burkhardt C., Burger D., Imboden I., Hassig M. and Thun R. (2005): Influence of repeated treadmill exercise on quality and freezability of stallion semen. Theriogenology, in print

Jasko D. J., Moran D. M., Farlin M. E. and Squires E. L. (1991): Effect of seminal plasma dilution or removal on spermatozoal motion characteristics of cooled stallion semen. Theriogenology 35, 1059-1067

Jasko D. J., Hathaway V. L., Schaltenbrand V. L., Simper W. D. and Squires E. L. (1992): Effect of seminal plasma and egg yolk on motion characteristics of cooled stallion spermatozoa. Theriogenology 37, 1241-1252

Jauhiainen A. and Vanha-Perttula T. (1987): Comparison of glycosidase levels in bovine seminal plasma. Int. J. Androl. 10, 489-494

Kareskoski A. M., Reilas T., Sankari S., Andersson M. and Katila T. (2005): Composition of fractionated stallion ejaculates. Anim. Reprod. Sci. 89, 228

Kareskoski A. M., Reilas T., Andersson M. and Katila T. (2006): Motility and plasma membrane integrity of spermatozoa in fractionated stallion ejaculates after storage. Reprod. Dom. Anim. 41, $33-$ 38 (in print)

Karow A. M., Gilbert W. B. and Black J. B. (1992): Effects of temperature, potassium concentration, and sugar on human spermatozoa motility: A cell preservation model from reproductive medicine. Cryobiology 29, 250-254

Katila T., Andersson M., Reilas T. and Koskinen E. (2002): Post-thaw motility and viability of fractionated and frozen stallion ejaculates. Theriogenology 58, 241-244

Katila T., Reilas T., Güvenc K., Alm K. and Andersson M. (2004): The effect of seminal plasma on motility characteristics and viability of spermatozoa after cooled storage. In: Proc. 3rd Meeting EEGG, Eds J. Müller, Z. Müller and J.F. Wade. Havemeyer Foundation Monograph Series No. 13, 3-5

Katila T., Kareskoski M., Akcay E., Reilas T., Koskinen E. and Calvete J. J. (2006): Seminal plasma studies in stallions. 4th Int. Equine Gamete Goup Meeting. Havemeyer Foundation Monograph Series No.18, 3-5 (in print)

Kneiss/ S. (1993): Tiefgefrierkonservierung von Pferdesperma: Einfluss der Sahmenentnahmetechnik, Zentrifugation, Konfektionierungsform und Einfriermethode auf die Motilität und Membranintegrität der Samenzellen (Cryopreservation of stallion semen: The influence of semen collection techniques, centrifugation, packaging forms, and methods of freezing on the motility and plasma membrane integrity of spermatozoa). Dissertation, Tierärztliche Hochschule Hannover

Kosiniak K. (1975): Characteristics of the successive jets of ejaculated semen of stallions. J. Reprod. Fert. Suppl. 23, 59-61 
Koskinen E., Karlsson M., Reilas T., Sankari S., Esala A.-L. and Katila T. (2002): Catalase activity and total protein in fractionated stallion seminal plasma. Theriogenology 58, 337-340

Langkammer S. (1994): Fraktionierte und nichtfraktionierte Samengewinnung beim Hengst: Vergleichende Untersuchungen zur Haltbarkeit von Frischsperma (Investigations on the keeping properties of fractionated and non-fractionated stallion semen). Dissertation, Tierärztliche Hochschule Hannover, Germany

Lapointe S., Ahmad I., Buhr M. M. and Sirard M.-A. (1996): Modulation of postthaw motility, survival, calcium uptake, and fertility of bovine sperm by magnesium and manganese. J. Dairy Sci. 79, 2163-2169

Leyton L., LeGuen P., Bunch D. and Saling P. M. (1992): Regulation of mouse gamete interaction by a sperm tyrosine kinase. Cell. Biol. 89, 11692-11695

Lindeberg H., Karjalainen H., Koskinen E. and Katila T. (1999): Quality of stallion semen obtained by a new semen collection phantom (Equidame ${ }^{\circledR}$ ) versus a Missouri ${ }^{\circledR}$ artificial vagina. Theriogenology 51, 1157-1173

Lopez M. L., Grez P., Gribbel I. and Bustos-Obregon E. (1989): Cyłochemical and ultrastructural characteristics of the stallion epididymis (Equus caballus). J. Submicrosc. Cytol. Pathol. 21, 103-120

Love C. (1992): Semen collection techniques. In: Stallion management, Eds. T.L.Blanchard and D.D. Varner. Vet. Clin. N.A.: Equine Pract. 8 (1), $111-128$

Magistrini M., Seguin F., Beau P., Akoka S. Le Pape A. and Palmer E. (1995): $1^{\mathrm{H}}$ nuclear magnetic resonance analysis of stallion genital tract fluids and seminal plasma: contribution of the accessory sex glands to the ejaculate. Biol. Reprod. Mono. 1, 599-607

Magistrini M., Lindeberg H., Koskinen E., Beau P. and Seguin F. (2000): Biophysical and $1^{\mathrm{H}}$ magnetic resonance spectroscopy characteristics of fractionated stallion ejaculates. J. Reprod. Fert. Suppl. 56, 101-110

Mann T., Minotakis C. S. and Polge C. (1963): Semen composition and metabolism in the stallion and jackass. J. Reprod. Fertil. 5, 109-518

Marquez B. and Suarez S. S. (2004): Different signaling pathways in bovine sperm regulate capacitation and hyperactivation. Biol. Reprod. 70, 1626-1633

Massanyi P., Trandzik J., Nad P., Toman R., Skalicka M. and Korenekova B. (2003): Seminal concentrations of trace elements in various animals and their correlations. Asian J. Androl. 5, 101-104

Métayer S., Dacheux F., Dacheux J.-L. and Gatti J.-L. (2002): Comparison, characterization, and identification of proteases and protease inhibitors in epididymal fluids of domestic mammals. Matrix metalloproteinases are major fluid gelatinases. Biol. Reprod. 66, 1219-1229

Moore A. I., Squires E. L. and Graham J. K. (2005): Effect of seminal plasma on the cryopreservation of equine spermatozoa. Theriogenology 63, 2372-2381

Padilla A. W. and Foote R. H. (1991): Extender and centrifugation effects on the motility patterns of slow-cooled stallion spermatozoa. J. Anim. Sci. 69, 3308-3313

Palmer E. (1984): Factors affecting stallion semen survival and fertility. 10th ICAR, Urbana-Champaign, Illinois, USA, vol III. 377-378

Parks J. E. and Lynch D. V. (1992): Lipid composition and thermotropic phase behavior of boar, bull, stallion, and rooster sperm membranes. Cryobiology 29, 255-266

Pena F. J., Johannisson A., Wallgren M. and Rodriguez-Martinez $\mathrm{H}$. (2003): Assessment of fresh and frozen-thawed boar semen using an Annexin- $V$ assay: a new method of evaluating sperm membrane integrity. Theriogenology 60, 677-689
Pesch S. K. (2005): Licht- und elektronenmikroskopische Untersuchungen am Hengstejakulat sowie biochemische Analysen des Seminalplasmas (Light- and electron microscopic studies on stallion ejaculate and biochemical analyses of seminal plasma). Dissertation, Justus-Liebig-Universität Giessen, Germany

Pruitt J. A., Arns M. J. and Pool K. C. (1993): Seminal plasma influences recovery of equine spermatozoa following in vitro culture $\left(37^{\circ} \mathrm{C}\right)$ and cold-storage $\left(5^{\circ} \mathrm{C}\right)$. Theriogenology 291

Rethinaswamy A., Yang C. and Srivastava P. N. (1994): Purification and characterization of $\beta$-glucuronidase from bull seminal plasma and its role in fertilization. Mol. Reprod. Dev. 38, 404-409

Rigby S. L., Brinsko S. P., Cochran M., Blanchard T. L., Love C. C. and Varner D. D. (2001): Advances in cooled semen technologies: seminal plasma and semen extender. Anim. Reprod. Sci. 68, 171-180

Rossato M., Balercia G., Lucarelli G., Foresta C. and Mantero F. (2002): Role of seminal osmolarity in the regulation of human sperm motility. Int. J. Androl. 25, 230-235

Shimokawa K., Katayama M., Matsuda Y., Takahashi H., Hara I., Sato H. and Kaneko S. (2002): Matrix metalloproteinase (MMP)-2 and MMP9 activities in human seminal plasma. Mol. Hum. Reprod. 8, 32-36

Sieme H., Beelmann V., Schröter N., Waberski D. and Klug E. (2001): Influence of stallion seminal plasma on vitality of liquid preserved semen, interval of ovulation and pregnancy rate. Anim. Reprod. Sci. 68, 315-316

Sorensen M. B., Bergdahl I. A., Hjollund N. H. I., Bonde J. P. E., Stoltenberg M. and Ernst E. (1999): Zinc, magnesium and calcium in human seminal fluid: relations to other semen parameters and fertility. Mol. Hum. Reprod. 5, 331-337

Tischner M., Kosiniak K. and Bielanski W. (1974): Analysis of pattern of ejaculation in stallions. J. Reprod. Fert. 41, 329-335

Todd P., Arns M. J., Chenoweth P. and Schultz B. (2001): Influence of seminal plasma and processing on cold-stored stallion spermatozoa. Anim. Reprod. Sci. 68, 335-336

Turner R. M. O. and McDonnell S. (2003): Alkaline phosphatase in stallion semen: characterization and clinical applications. Theriogenology 60, $1-10$

Töpfer-Petersen E., Waberski D., Hess O., Bellair S., Schambony A., Ekhlasi-Hundrieser M., Gentzel M. and Reineke A. (1998): Bedeutung des Seminalplasmas für die Befruchtung - ein kurzer Überblick (The role of seminal plasma in fertilization - a short overview). Tierärztl. Umschau 53, 447-454

Varner D. D., Blanchard T. L., Love C. L., Garcia M. C. and Kenney R. M. (1987): Effects of semen fractionation and dilution ratio on equine spermatozoal motility parameters. Theriogenology 28, 709-723

Webb G. W. and Arns M. J. (1995): Influence of modified Tyrode's media on motility of cool-stored stallion spermatozoa. J. Equine Vet. Sci. 15, 441-444

\section{Prof. Terttu Katila}

University of Helsinki,

Faculty of Veterinary Medicine

Department of Clinical Veterinary Sciences

Saari Unit

Pohjoinen Pikatie 800

04920 Saarentaus

Finland

terttu.katila@helsinki.fi 